\title{
A SCALE FOR MERIT IN ENGLISH WRITING BY YOUNG PEOPLE.
}

\author{
EDWARD L. THORNDIKE, \\ Teachers College, Columbia Vniversity.
}

An ideal scale for merit in English writing would eonsist of a series of compositions (1) which range from one that possessed zero merit to one that possessed the utmost possible merit, (2) whose respective amounts or degrees of merit were exactly known and whose nature was such that other composi. tions could be compared with them easily.

Such a scale would obviously be of great value to teachers, civil-service examiners, college-entrance boards, scientific students of education and any others who need to measure the merit of specimens of English writing in order to estimate the abilities of individuals or changes in such abilities as the result of mental maturity, educational effort and other causes.

The best service toward establishing such a scale is the pro. vision of an approximate seale by the extension, amplification and refinement of which more and more adequate scales may be divised. In this work Mr. M. B. Hillegas and I are at present engaged. Certain results so far obtained are presented in this article, partly because of their intrinsic value, and partly because it will be of interest to the readers of $\mathrm{THE}_{\mathrm{HE}}$ Journal to criticize them and so aid in the improvement of the scale.

The best introduction to what follows will be for the reader to. himself make the following experiment:-

Examine the following specimens and rank them in order for what you regard as merit in English writing by young people. Number the worst specimen 1 , the next worse 2 , the next worse 3 , and so on. Then let the four-inch line below represent the total difference in merit between the specimen which 
you rank 1, or worst, and the specimen which you rank 18, or best, and place the letters designating your numbers $4,7,10$, 13 and 16 at appropriate points, so that the distances between these points represent the respective differences in merit between $1,4,7,10,13,16$ and 18 in your judgment. Then decide what sort of English writing would possess zero, or "just not any," merit as writing by young people and locate this zeropoint where it belongs on the line or an extension of it.

(a) When Sulla came back from his conquest Marius has put himself consul so sulla with the army he had vith him in his conquest siezed the government from Marius and put himself in consul and had a list of his enemys printy and the wen whoes names were on this list we beheaded.

(b) Ichabod Crane was a schoolmaster in a place called Sleepy Hollow. He was tall and slim with broad shoulders, long arms that dangled far below his cuat sleeves. His feet looket as if they might easily have been used for shovels. His nose was long and his entire frame was most loosely hung to-gether.

(c) My dear Fred,-

I will tell you of my fourney to Delphi Falls, $N$. $\mathbf{X}$. There is nice scenery along this rouie. The prettlest scene is in the gulf which is quite narrow, a small creck flows down it and the roud follows along near its banks.

There are woods on elther side, these trees look very pretty when they are white with snow.

In summer it is always sluady and cool in them and the small fish may be seen darting back and forth in the water.

I hope I will bave the pleasure of taking you over the route some time.

Yours sincerely,

(d) As we road down Lombard street we saw flags waving from nearly every window. I surely felt proud that day to be the driver of the gally decorated coach. Again and again we were cheered as we drore slowly to the postmasters, to await the coming of his majestie's mall. There wasn't one of the gaily bedecked coaches that could have compared with ours, in my estimation. So with waving flage and fluttering hearts we waited for the coming of the mail and the expected tidings of victory.

When at last it did arrire the postmaster began to quickly sort the bondles, we waited anxiously. Immediately upon receiving our bundles, I lashed the horses and they responded with a fump. Ont into the country we drove at reckless speed-everywhere spreading like wlldfire the news, "Victory!" The exdleration that we all felt was shared with the horses. Up and down grade and over bridges, we drove at breakneck speed and spreading the news at every hamlet with that one cry "Victory!" When at last we were back home again, it was with the hope that we should have another ride some day with "Vietory."

(e) The most popular man of Auburn was the preacher. Although he had a very small salary he was contented. The preacher was kind to everybody. Little children loved him. Old soldiers liked to sit by hls fireside and tell atories of the battles, which they had fought in. The beggars who came to hils door, although chided for leading such an exlstence, were always clothed and feed.

The preacher was always willing to go to the homes where there was stckness or death. Here be helped in all things that he could. 
In the church he preached with unaffected grace, and all who came to scofr at him remained to worship.

The minister was a contented, simple and kind man, whom the people loved.

(f) As far as I can learn froin the Bssay on Burns, Mr. Carlyle considers thut good poetry must contain the sincerity of the poet. The poem must show the author's good cholce of subject and his clearness of sight. In order to have good poetry the pbet mast be familiar with his subject and his poem will show it.

The characteristics of $n$ great poet, in Mr. Carlyle's opinion were sincerity and choice of subjects. A poet must be appreclative of nature and have a responding beart. Carlyle says a true poet does no have to write on subjects which are far away and probably come from the clouds. A truly great poet makes the most of subjects which are familiar to him and close to earth, as Burns did in his poems to the Field Mouse and to The Daisey.

(g) I had an early run in the woods before the dew was of the grass. The moss was like velvet and as I ran under the arches of yellow and red leaves $I$ sang for joy, my heart was so bright and the world was so beautiful. I stopped at the end of the walk and saw the sunshine out over the wide "Virginia meadows."

Ie semed like going through a dark life or grave into heaven beyond. A very strange and solemn feeling same over me as I stood there, with no sound but the rustle of the pines, no one near me, and the sun so glorious, as for me alone. It seemed as if I felt God as I never did before, and I prayed in my heart that $I$ might keep that happy sense of nearness all my life.

(h) dere techer :

I like schol not like schol. that man other place like make work tools. Some day you say I rede

(i) First: De Quincys mother was a beautiful women and through her De Quincy inhereted much of his genius.

His running a way from school enfluenced him much as he roamed through the woods, ralleys and his mind becrme very meditative.

The greatest enfluence of De Quincy's life was the opium habit. If it was not for this habit it is doubtful whether we would now be reading his writings.

His companlons during his college course and even before that time were sreat enflnences. The surroundings of De Quincy were enfluences. Not only De Quincy's habit of opinm but other habits which were peculiar to his life.

His mariage to the woman which he did not especially care for.

The many well educated and noteworthy friends of De Quincy.

(j) They were In fact very fine ladies; not deficient in good humour when they were pleased, nor in the power of being agreeable when they chose it, but proud and conceited. They were rather handsome, had been educated in one of the first private seminaries in town, had a fortune of twenty thousand pounds, were in the habit of spending more than they ought, and of associating with people of rank, and were therefore in every respect entitled to think well of theuselves, and weanly of others.

(k) The passages glven show the following characteristics of Fluellen: his inclination to brag, his professed knowledge of History, his complaining character, his great patriotism, pride of his leader, admired honesty, revengefnl, love of fun and punishment of those who deserve it.

(l) Our school room is on the side of the school house and it is a awfully nice room and $I$ like it becanse it is so nice and all the boys like it, there is a good 
many pictures on the wall and there is a clock on the wall. We like this school room und come to school most all tile time.

(in) Wear Sir: I write to say that it aint a square deal Schools is I say they is $I$ went to a school. red and gree green and brown aint it hito bit $I$ say be don't know his business not today nor yeaterday and you know it and I want Jennie to get me out.

(n) the book I refer to read is Ichabod Crane, it is an grate book and I like to rede it. Ichabod Crame was a man and a man wrote a book and it is called Ichabod Crane i like it because the innn called it lchabod crane when I read it for it is such a great book.

(o) I words four and two cume go billa guni sing hay cows and horses be done It good he died it goon I want yes sir yes sir oxes and sheeps be come yes sir camed and goes billum gumun oownnn goodum.

(p) Advantage evils are things of tyranny and there are many advantage evils. One thing is that when they opress the people they suffer awful $I$ think it is a terrible thing when they say that sou can be hanged down or trodden down without mercy and the tyranny does what they want there was tyrans in the revolutionary war and so they throwed off the yok.

(q) I think the sumlight is very beautiful on the water, and when it shines on the water 'it is very beautiful, and I love to watch it when it is so beautiful. The colors are so pretty and the noise of the water with the sunshine are so attractive in the sunshine $I$ wonder do other people love to watrh the water like I do. I dont know as there is anything as lorely as the water waves in the sunlight of the glorious orb.

(r) I want to suy it aint no youse thex aint got no right and they aint got no man ban tan pan ran san san sen sen sun sun tan ton

This experiment is suggested primarily as the quickest and clearest introduction to what follows, and as of interest because it permits the reader to compare his own personal judgments with the average judgment (to be given later) of nearly two hundred competent judges. But I beg the reader, having thus made his independent judgments, to cut out or copy the blank on the opposite page and send it as directed.

The hypotheses upon which the scale is constructed are the following:-

1. Two specimens of English composition, $A$ and B, are equal if, among competent judges, just as many judge $A$ to possess more merit than $B$ as judge $B$ to possess more merit than $A$. If all judges are forced to express a preference, cquality in merit means 50 per cent. of preferences. Specimen $r$ is thus judged about equal to specimen $s$, being judged better .51 , and worse 56 times by 107 judges. 
I rank the specimens as follows :-
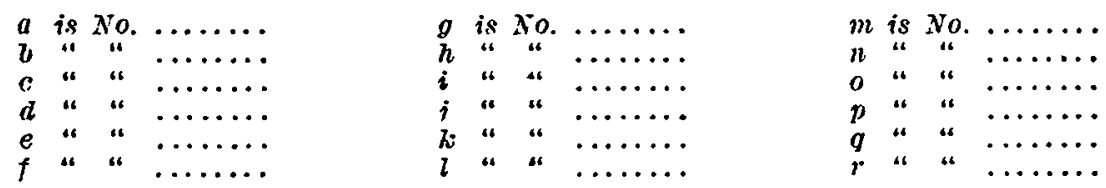

- I locate my grades 4, 7, 10, 13 and 15, and the point of just not any merit as English writing by a person in his 'teens, as shown below:-

\section{Name,}

Address,

Please send this, or a copy, to E. L. Thorndike, Teachers College, Columbia University.

2. The differences between $C$ and $D$ and between $\mathrm{I}$ and $\mathrm{E}$ are equal if, among competent judges, forced to express a preference, the.per cent judging $C$ to possess more merit than $D$ equals the per cent judging $D$ to possess more merit than E. Specimen $d$ is thus approximately as far above specimen $b$ as $b$ is above $k, 151$ out of 180 judges calling $d$ better than $b$, and 146 of them calling $b$ better than $k$.

3. Within certain limits and approximately, the difference between $F$ and $G$ bears a relation to the difference between $G$ and $H$, as shown in the following table:-

\section{TẢBLE I.}

The relation of the amount of difference in merit between $x$ and $y$ to the frequency of judgments that " $x$ is better than $y$," only judgments " $x$ better than $y$ ". or " $x$ worse than $y$ " being allowed.

(8) ifrom thre ours up in room on books and books care for chllder tore a page and rite on them 
TEE JOURNAL OF EDUCATIONAL PSYChOLOGY.

\begin{tabular}{|c|c|c|c|}
\hline $\begin{array}{l}\text { Percentage of } \\
\text { judges regard- } \\
\text { ing } x \text { as bet- } \\
\text { ter than } y \text {. }\end{array}$ & $\begin{array}{l}\text { Amorint of } \\
\text { superiority } \\
\text { of } x \text { to } y \text {, } \\
100 \text { equaling } \\
\text { that amount } \\
\text { which causes } \\
75 \text { per cent } \\
\text { of the fudges } \\
\text { to judge } x \text { as } \\
\text { better than } \\
y \text {. }\end{array}$ & $\begin{array}{l}\text { Percentage of } \\
\text { judges regard- } \\
\text { ing } x \text { as bet- } \\
\text { ter thall } y \text {. }\end{array}$ & $\begin{array}{l}\text { Amount } \\
\text { superlori } \\
\text { of } x \text { to } \\
100 \text { equa } \\
\text { that amo } \\
\text { which car } \\
\text {-75 per } \\
\text { of the fuc } \\
\text { to judge } \\
\text { better t } \\
y .\end{array}$ \\
\hline $\begin{array}{l}50 \\
51 \\
52 \\
53 \\
54\end{array}$ & $\begin{array}{r}0 \\
4 \\
7 \\
11 \\
15\end{array}$ & $\begin{array}{l}75 \\
76 \\
77 \\
78 \\
79\end{array}$ & $\begin{array}{l}100 \\
105 \\
110 \\
114 \\
120\end{array}$ \\
\hline $\begin{array}{l}55 \\
56 \\
57 \\
58 \\
59\end{array}$ & $\begin{array}{l}19 \\
22 \\
26 \\
30 \\
34\end{array}$ & $\begin{array}{l}80 \\
81 \\
52 \\
83 \\
84\end{array}$ & $\begin{array}{l}125 \\
130 \\
136 \\
141 \\
147\end{array}$ \\
\hline $\begin{array}{l}60 \\
61 \\
62 \\
63 \\
64\end{array}$ & $\begin{array}{l}38 \\
41 \\
45 \\
49 \\
53\end{array}$ & $\begin{array}{l}85 \\
86 \\
87 \\
88 \\
S 9\end{array}$ & $\begin{array}{l}154 \\
160 \\
167 \\
174 \\
182\end{array}$ \\
\hline $\begin{array}{l}65 \\
66 \\
67 \\
68 \\
69\end{array}$ & $\begin{array}{l}57 \\
61 \\
65 \\
69 \\
74\end{array}$ & $\begin{array}{l}90 \\
91 \\
92 \\
93 \\
94\end{array}$ & $\begin{array}{l}190 \\
199 \\
208 \\
219 \\
231\end{array}$ \\
\hline $\begin{array}{l}70 \\
71 \\
72 \\
73 \\
74\end{array}$ & $\begin{array}{l}78 \\
82 \\
86 \\
91 \\
95\end{array}$ & $\begin{array}{l}95 \\
96 \\
97 \\
98 \\
99\end{array}$ & $\begin{array}{l}244 \\
260 \\
279 \\
305 \\
345\end{array}$ \\
\hline
\end{tabular}

F'or example, specimen $\mathrm{h}$ is judged by 80 out of 107 judges, or 75 per cent, to possess more merit than specimen $r$; and $r$ is judged to be better than specimen o by 76 of the 107 judges, or 71 per cent. By the table, then, $h$ differs from $\mathrm{r}$ by +100 , and $\mathrm{r}$ differs from o by $+82 ; \mathrm{h}-\mathrm{r}=100$ and $\mathrm{r}-\mathrm{o}=82$.

I need not here discuss the basis, in theory and experiment, for Table I. Common sense informs us that if $\mathrm{J}$ is judged better than $K$ by 90 out of 100 judges and $K$ better than $L$ by only 70 out of 100 , the difference $J-K$ is greater than the difference $K-L$. Table I informs us how much greater, supposing certain facts about the causation of individual differences in judgment to be true. On any defensible view whatever of these facts, 
the table is approximately valid so long as we use it only to compare differences of about the same amount.

With 180 judges, the results were, for some of the specimens above :-

$$
\begin{aligned}
& \text { g better than d, } 142 \text { or } 79 \% \text {; g worse d, } 38 \text { or } 21 \% \text {. } \\
& \text { b " " } k, 126 \text { " } 70 \% ; b \text { " } k, 54 \text { " } 30 \% \text {. } \\
& \text { k " " q, } 148 \text { " } 82 \% ; k \text { " } \mathrm{q}, 32 \text { " } 18 \% \text {. } \\
& \text { q “ " } \quad \text { a, } 119 \text { “ } 66 \% ; \mathrm{q} \text { “ } \mathrm{a}, 61 \text { “ } 34 \% \text {. }
\end{aligned}
$$

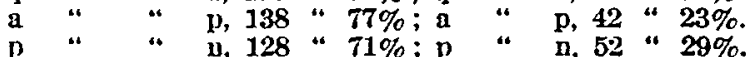

The following relative differences calculated from Table I are approximately correct by any defensible method of calculation. One hundred equals the degree of difference noticed correctly by 75 per cent of judges :

$$
\begin{aligned}
& g-d=120 \\
& d-b=91 \\
& b-k=78 \\
& k-q=136 \\
& q-a=61 \\
& a-p=108 \\
& p-n=82
\end{aligned}
$$

The difference between $\mathbf{n}$ and zero merit is found, in a way that I shall presently describe, to be approximately 180. Sample $m$ is on the whole regarded as of zero, or 'just not any,' merit as English writing by a young person.

In so far, then, as the judges are competent, the specimens $a, b, d$, and so forth have amounts of merit as follows :--

$$
\begin{aligned}
& g=857 \\
& d=737 \\
& b=646 \\
& b=568 \\
& q=432 \\
& a=371 \\
& p=262 \\
& n=180 \\
& m=0
\end{aligned}
$$

The location of the zero point for merit in English composition hy young people is of importance in order to allow the 'times as much merit' judgment. Measures of fatigae, practice or change of any sort will be greatly facilitated if we can so arrange the scale that 8,10 and 12 on it mean twice as far from just not any of the thing in question as 4,5 and 6 -that 240 means twice as much of the thing as 120 , three times as 
much as 80 , five times as much as 48 . Hitherto no one could say with any assurance whether specimen $g$ was two, ten or a hundred times as 'good' as specimen q.

$I$ have located it approximately as specimen $m$ on the basis of the judgments of (1) nine men of special literary ability, five professors of Fnglish, four being authors of standard textbooks on composition, and four men of marked general intellect and literary ability; (2) eleven gifted teachers familiar with secondary education, and (3) eight psychologists familiar with the significance of scales and zero points in the case of intellectual abilities and products.

Although no one person of these had any deliberate criterion for the point where positive merit just begins, and altiough one's first reaction to the request to locate such a point is to regard it as arbitrary, there is much agreement amongst individuals and almost perfect agreement in the case of the averages of the three groups.

Of the twenty-eight judges, two regard zero merit as something below the least meritorious specimen of the list, and five put it higher than specimen $p$, but three-fourths of the judges locate it as not lower than specimen o or higher than specimen n. The central tendency of the twenty-eight puts it at specimen $\mathrm{m}$.

It is beyoud the scope of this article to comment on any facts obtained in the conrse of the derivation of the scales. But it will interest students of individual psychology and of the teaching of English to learn that the worst writing actually lound hy us amongst our 5000 excerpts from answers to examination questions written by pupils in the upper grammar and high-school grades is, by our scale, little below 400 . The best found in the same series is under 800 . Zero merit being defined by the consensus of impartial experts, the best paragraph by a pupil in his 'teens is little over twice as good as the worst paragraph produced by any high-school pupil. To get grades from 400 down it was necessary to make artificial specimens. To write an English sentence that intelligently, tho' very offensively, expresses an idea of any complexity, means ap. parently progress nearly half way from zero to the limit of achievement for a pupil in his 'teens. 